\title{
A New Antioxidant, Clitocybin A, from the Culture Broth of Clitocybe aurantiaca
}

\author{
Young-Hee Kim, Sung-Min Cho, Jin-Won Hyun, In-Ja Ryoo, Soo-Jin Choo, \\ Sangku Lee, Soon-Ja Seok, Jae Sung Hwang, Eui Dong Sohn, Bong-Sik Yun, \\ Ki Hwan Bae, Ick-Dong Yoo
}

Received: June 20, 2008 / Accepted: August 28, 2008

(C) Japan Antibiotics Research Association

\begin{abstract}
Clitocybin A (1), a new antioxidant, was isolated from the culture broth of Clitocybe aurantiaca. This compound was purified by solvent extraction, silica gel column chromatography, Sephadex LH-20 column chromatography and preparative HPLC. Its structure was determined as 4,6-dihydroxy-2- $\rho$-hydroxyphenyl-isoindol1-one on the basis of the UV, NMR, and MS spectroscopic analysis. The compound $\mathbf{1}$ showed potent free radical scavenging activity against superoxide, ABTS, and DPPH radicals, and protective effect against cellular DNA damage induced by oxidative stress.
\end{abstract}

Keywords clitocybin A, Clitocybe aurantiaca, antioxidant activity, comet assay

Free radicals are considered to induce oxidative damage in biomolecules and to play an important role in aging, cardiovascular diseases, cancer, and inflammatory diseases [1]. In addition, they are also well known to be major causes of material degradation and food deterioration. Consequently, antioxidants are now known to be protective or therapeutic agents [2]. In the past few years, the addition of synthetic antioxidants has begun to be restricted, because of their health risks and toxicity. The importance of exploiting natural antioxidants from various sources and replacing synthetic antioxidants with natural ingredients has attracted increasing attention. Most natural antioxidants such as traditional nutrients, polyphenols, and flavonoids are obtained from plants. Recently, mushrooms have been reported to harbor a host of bioactive substances [3, 4]. The study of known and new natural derivatives in higher fungi might also support the development of new drugs, as well as health-promoting substances.

In the course of our screening program for free radical scavengers, we isolated a novel compound, clitocybin A (1, Fig. 1), from the culture broth of Clitocybe aurantiaca [5, 6]. In this paper, we report upon the isolation, structure elucidation and biological activities of $\mathbf{1}$. We were provided this strain from the staff of mushroom taxonomy laboratory at the National Institute of Agricultural Science and Technology.

The producing strain, $C$. aurantiaca, was cultivated in a producing medium consisting of $2.0 \%$ glucose, $0.5 \%$ polypeptone, $0.2 \%$ yeast extract, $0.1 \% \mathrm{KH}_{2} \mathrm{PO}_{4}$ and $0.05 \%$ $\mathrm{MgSO}_{4} \cdot 7 \mathrm{H}_{2} \mathrm{O}(\mathrm{pH} 0.6 \sim 5.8)$ for 7 days at $28^{\circ} \mathrm{C}$ on a reciprocal shaker. The whole cultured broth (3.0 liters) was
I.-D. Yoo (Corresponding author), Y.-H. Kim, S.-M. Cho, I.-J. Ryoo, S.-J. Choo, S. Lee, B.-S. Yun: Functional Metabolomics Research Center, Korea Research Institute of Bioscience and Biotechnology, Daejeon 305-806, Korea,

E-mail: idyoo@kribb.re.kr

J.-W. Hyun: College of Medicine, Cheju National University, Jeju 690-756, Korea
S.-J. Seok: National Institute of Agricultural Science and Technology, RDA, Suwan 441-707, Korea

J.-S. Hwang, E.-D. Sohn: Amorepacific Corporation R\&D Center, Giheung, Gyeonggi, 442-729, Korea

K.-H. Bae: Department of Pharmacy, Chungnam National University, Daejeon 305-764, Korea 
<smiles>O=C1c2cc(O)cc(O)c2CN1c1ccc(O)cc1</smiles>

Clitocybin A

Fig. 1 Structure of clitocybin A.

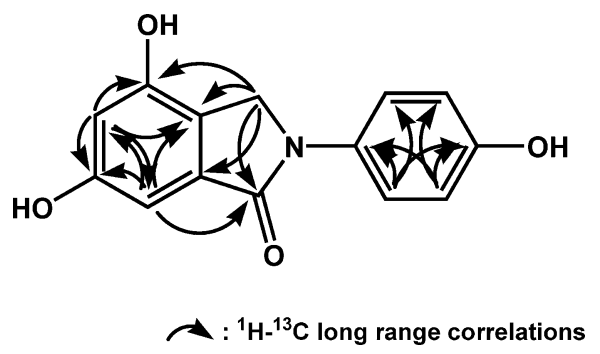

Fig. $2 \mathrm{HMBC}$ correlations of clitocybin $\mathrm{A}$.

sequentially extracted with $n$-hexane and EtOAc. The EtOAc layer was concentrated and applied to a column of silica gel eluted with $\mathrm{MeOH}-\mathrm{CHCl}_{3}(1: 50 \sim 1: 1, \mathrm{v} / \mathrm{v})$. The active eluate was then chromatographed on a Sephadex LH-20 column eluted with $\mathrm{MeOH}$. Finally, 1 was obtained by HPLC using a YMC-pack ODS-A column $(4.6 \mathrm{~mm}$ i.d. $\times 150 \mathrm{~mm}$ ) eluted with $30 \% \mathrm{MeOH}$.

The physico-chemical properties of $\mathbf{1}$ are summarized in Table 1. The molecular formula of $\mathbf{1}$ was established as $\mathrm{C}_{14} \mathrm{H}_{11} \mathrm{NO}_{4}$ by high-resolution ESI-mass measurement. IR absorptions at 3399 and $1616 \mathrm{~cm}^{-1}$ implied the presence of hydroxyl groups and amide moieties, respectively. A heteronuclear multiple-quantum coherency (HMQC) experiment established all one-bonded ${ }^{1} \mathrm{H}-{ }^{13} \mathrm{C}$ connectivity, as shown in Table 2. The ${ }^{1} \mathrm{H}-\mathrm{NMR}$ spectrum of $\mathbf{1}$ displayed signals for one methylene proton and six aromatic protons. The ${ }^{13} \mathrm{C}$-NMR spectrum of 1 revealed the presence of 14 carbons comprised of one $s p^{3}$ methylene, six $s p^{2}$ methines and seven quaternary carbons including an amide carbonyl and three oxygenated $s p^{2}$ carbons. The HMBC spectrum of 1 revealed two partial structures, isoindolone moiety and 1,4-disubstituted benzene group, as shown in Fig. 2. In the isoindolone moiety, a methylene protons at $\delta 4.71$ showed long range correlations to $\mathrm{C}-1\left(\delta_{\mathrm{C}} 172.4\right), \mathrm{C}-3 \mathrm{a}\left(\delta_{\mathrm{C}} 120.6\right)$, $\mathrm{C}-4\left(\delta_{\mathrm{C}} 155.4\right)$ and $\mathrm{C}-7 \mathrm{a}\left(\delta_{\mathrm{C}} 136.4\right)$. In addition, the longrange correlations from $\mathrm{H}-5$ to $\mathrm{C}-3 \mathrm{a}\left(\delta_{\mathrm{C}} 120.6\right), \mathrm{C}-4\left(\delta_{\mathrm{C}}\right.$ $155.4), \mathrm{C}-6\left(\delta_{\mathrm{C}} 162.2\right)$, and $\mathrm{C}-7\left(\delta_{\mathrm{C}} 102.0\right)$, and from $\mathrm{H}-7$ to $\mathrm{C}-1\left(\delta_{\mathrm{C}} 172.4\right), \mathrm{C}-3 \mathrm{a}\left(\delta_{\mathrm{C}} 120.6\right), \mathrm{C}-5\left(\delta_{\mathrm{C}} 108.0\right)$ and C-6 $\left(\delta_{\mathrm{C}} 162.2\right)$ were observed. The long-range correlations
Table 1 Physico-chemical properties of clitocybin A

\begin{tabular}{ll}
\hline & \multicolumn{1}{c}{ Clitocybin A } \\
\hline Appearance & Pale brown powder \\
{$[\alpha]_{D}^{20}$} & $-1.40^{\circ}(c 0.3, \mathrm{MeOH})$ \\
Molecular formular & $\mathrm{C}_{14} \mathrm{H}_{11} \mathrm{NO}_{4}$ \\
Molecular weight & 257 \\
HR-ESI-MS m/z & \\
$\quad$ Found & $258.07571\left(\mathrm{M}+\mathrm{H}^{+}\right)$ \\
$\quad$ Calcd. & 258.07608 \\
UV $\lambda_{\max }^{\text {MeO }} \mathrm{nm}(\log \varepsilon)$ & $211(1.6), 286(0.4)$ \\
IR $v_{\max }(\mathrm{KBr}) \mathrm{cm}^{-1}$ & $3399,2925,1616,1516,1453,1256$, \\
& 1144,1097 \\
Soluble & MeOH, DMSO \\
Insoluble & $n$-hexane, $\mathrm{H}_{2} \mathrm{O}$ \\
\hline
\end{tabular}

Table $2{ }^{1} \mathrm{H}$ - and ${ }^{13} \mathrm{C}-\mathrm{NMR}$ data of clitocybin $\mathrm{A}$ in methanol- $d_{4}$

\begin{tabular}{lrl}
\hline Position & \multicolumn{1}{c}{$\delta_{\mathrm{C}}$} & \multicolumn{1}{c}{$\delta_{\mathrm{H}}$} \\
\hline 1 & 172.4 & \\
3 & 50.3 & $4.71(\mathrm{~s})$ \\
$3 \mathrm{a}$ & 120.6 & \\
4 & 155.4 & \\
5 & 108.0 & $6.50(\mathrm{~d}, J=1.8 \mathrm{~Hz})$ \\
6 & 162.2 & $6.71(\mathrm{~d}, J=1.8 \mathrm{~Hz})$ \\
7 & 102.0 & \\
$7 \mathrm{a}$ & 136.4 & $7.54(\mathrm{~d}, J=9.0 \mathrm{~Hz})$ \\
8 & 133.9 & $6.84(\mathrm{~d}, \mathrm{~J}=9.0 \mathrm{~Hz})$ \\
9,13 & 124.7 & \\
10,12 & 117.6 & \\
\hline 11 & 157.9 & \\
\hline
\end{tabular}

Chemical shift in ppm from TMS as internal standard.

${ }^{1} \mathrm{H}$ - and ${ }^{13} \mathrm{C}-\mathrm{NMR}$ were measured at 600 and $150 \mathrm{MHz}$, respectively.

from methine proton at $\delta 7.54$ to $\mathrm{C}-8\left(\delta_{\mathrm{C}} 133.9\right), \mathrm{C}-11\left(\delta_{\mathrm{C}}\right.$ $157.9)$ and $\mathrm{C}-13\left(\delta_{\mathrm{C}} 124.7\right)$, and from methine proton at $\delta$ 6.84 to $\mathrm{C}-8\left(\delta_{\mathrm{C}} 133.9\right), \mathrm{C}-11\left(\delta_{\mathrm{C}} 157.9\right)$ and $\mathrm{C}-12\left(\delta_{\mathrm{C}}\right.$ 117.6) revealed the presence of a 1,4-disubstituted benzene moiety. Based on the above HMBC experiment, 1 was assigned as a new compound of isoindolone class.

The antioxidant activity of $\mathbf{1}$ was evaluated by measuring its free radical scavenging effects using three different assays, the superoxide radical anion scavenging activity assay, ABTS (2,2'-azino-bis-[3-ethylbenzothiazoline-6sulfonic acid]) radical cation decolorization assay, and DPPH (2,2-diphenyl-1-picrylhydrazyl) radical scavenging assay (Table 3 ). The superoxide anion scavenging activity 
Table 3 Free radical scavenging activities of clitocybin A $\left(\mathrm{IC}_{50} \mu \mathrm{M}\right)$

\begin{tabular}{lccc}
\hline Compound & Superoxide radical $^{\mathrm{a}}$ & ABTS radical $^{\mathrm{b}}$ & DPPH radical \\
\hline Clitocybin A & $10.3 \pm 1.8$ & $6.4 \pm 0.2$ & $>100$ \\
Catechin & $16.0 \pm 0.9$ & $5.6 \pm 0.2$ & $57.5 \pm 2.5$ \\
Ferulic acid & $48.4 \pm 2.6$ & $7.1 \pm 0.1$ & $>100$ \\
\hline
\end{tabular}

${ }^{a}$ Xanthine/xanthine oxidase.

b 2,2'-Azino-bis-(3-ethylbenzothiazoline-6-sulfonic acid).

c2,2-Diphenyl-1-picrylhydrazyl.

In all three assays, results percentaged as the mean $(n=3) \pm S D$.

was evaluated by the xanthine/xanthine oxidase method [7]. In brief, each well of a 96-well plate containing $100 \mu \mathrm{l}$ of the following reagents: $50 \mathrm{mM}$ potassium phosphate buffer $(\mathrm{pH} 7.8), \quad 1.0 \mathrm{mM}$ EDTA, $0.04 \mathrm{mM}$ NBT (nitroblue tetrazolium), $0.18 \mathrm{mM}$ xanthine, $250 \mathrm{mU} / \mathrm{ml}$ xanthine oxidase, and the sample at various concentrations was incubated for 30 minutes at $37^{\circ} \mathrm{C}$ in the dark. The xanthine oxidase catalyzes the oxidation of xanthine to uric acid and superoxide, and the superoxide reduces NBT to blue formazan. The reduction of NBT to blue formazan was measured at $560 \mathrm{~nm}$ in a microplate reader. As a result, 1 exhibited potent superoxide radical scavenging activity with an $\mathrm{IC}_{50}$ value of $10.3 \mu \mathrm{M}$, which was comparable to those of well-known antioxidants, catechin and ferulic acid, used as a control.

The ABTS radical scavenging activity was measured using the ABTS radical cation decolorization assay with minor modifications [8]. ABTS was dissolved in water to a concentration of $7.0 \mathrm{mM}$. The ABTS ${ }^{\cdot+}$ cation radical was produced by reacting the ABTS stock solution with $2.45 \mathrm{mM}$ potassium persulfate and by allowing the mixture to stand in the dark for 12 hours. After adding $0.1 \mathrm{ml}$ of the ABTS radical cation solution to $5.0 \mu 1$ of the antioxidant compounds in EtOH, the absorbance was measured by an ELISA reader at $734 \mathrm{~nm}$ after mixing for up to 6 minutes. The compound $\mathbf{1}$ exhibited a significant ABTS radical cation scavenging effect with an $\mathrm{IC}_{50}$ value of $6.4 \mu \mathrm{M}$.

To investigate the scavenging effect on the DPPH radicals, 1 at various concentrations was added to $95 \mu 1$ of $150 \mu \mathrm{M}$ DPPH EtOH soln, the mixture was incubated for 20 minutes at room temperature, and the absorbance was measured at $517 \mathrm{~nm}$ using an ELISA reader [9]. The compound 1 showed no activity against the DPPH radical.

The ability of $\mathbf{1}$ to inhibit cellular DNA damage in $\mathrm{H}_{2} \mathrm{O}_{2}$ treated cells was investigated by the comet assay, which assesses oxidative DNA damage [10,11]. The cells used in this experiment was Chinese hamster lung fibroblast cells
Table 4 Protective effect of clitocybin A on DNA damage induced by $\mathrm{H}_{2} \mathrm{O}_{2}$

\begin{tabular}{|c|c|}
\hline Group & DNA tail $(\%)^{*}$ \\
\hline Control & $5.7 \pm 0.7$ \\
\hline $\mathrm{H}_{2} \mathrm{O}_{2}$ & $61.1 \pm 2.4$ \\
\hline Clitocybin $A^{a}$ & $7.0 \pm 0.8$ \\
\hline Clitocybin $\mathrm{A}^{\mathrm{a}}+\mathrm{H}_{2} \mathrm{O}_{2}$ & $35.4 \pm 2.6$ \\
\hline $\mathrm{N}$-Acetylcysteine ${ }^{\mathrm{b}}+\mathrm{H}_{2} \mathrm{O}_{2}$ & $16.2 \pm 1.3$ \\
\hline
\end{tabular}

${ }^{a}$ Concentration of clitocybin A was at $10 \mu \mathrm{g} / \mathrm{ml}$.

${ }^{\mathrm{b}}$ Concentration of $\mathrm{N}$-acetylcysteine was at $2.0 \mathrm{mM}$.

$*$ Results percentaged as the mean $(n=3) \pm$ SE.

(V79-4). Concentration of $\mathrm{H}_{2} \mathrm{O}_{2}$ was $1.0 \mathrm{mM}$. The cell pellets were applied to electrophoresis, stained with ethidium bromide and observed using a fluorescence microscope and image analysis. The percentage of total fluorescence in the tail and the tail length of 50 cells per slide were recorded. The comet assay showed that the exposure of the cells to $\mathrm{H}_{2} \mathrm{O}_{2}$ increased their tail length to 61.1, whereas their treatment with 1 resulted in a decrease of their tail length to 35.4 as shown in Table 4. This data suggested that $\mathbf{1}$ had a protective effect against cellular DNA damage induced by oxidative stress.

Acknowledgment This work was supported by a grant from the Korea Health 21 R\&D Project, Ministry of Health \& Welfare, Republic of Korea (A-050432).

\section{References}

1. Palinski W, Rosenfeld ME, Yla HS, Gurtner GC, Socher SS, Butler SW, Parthasarathy S, Careow TE, Steinberg D, Witztum JL. Low density lipoprotein undergoes oxidative modification in vivo. Proc Natl Acad Sci USA 86: 1372-1376 (1989)

2. Solak MH, Kalmis E, Saglam H, Kalyoncu F. Antimicrobial activity of two wild mushrooms Clitocybe alexandri (Gill.) Konr. and Rhizopogon roseolus (Corda) T.M. Fries collected from Turkey. Phytother Res 20: 1085-1087 (2006)

3. Yoo NH, Kim JP, Yun BS, Ryoo IJ, Lee IK, Yoon ES, Koshino H, Yoo ID. Hirsutenols D, E and F, new sesquiterpenes from the culture broth of Stereum hirsutum. J Antibiot 59: 110-113 (2006)

4. Kim YH, Yun BS, Ryoo IJ, Kim JP, Koshino H, Yoo ID. Methoxylaricinolic acid, a new sesquiterpene from the fruiting bodies of Stereum ostrea. J Antibiot 59: 432-434 (2006)

5. Arnone A, Colombo A, Nasini G, Meille SV. Secondary mold metabolites. Part 42. Eleganthol, a sesquiterpene from 
Clitocybe elegans. Phytochemistry 32: 1493-1497 (1993)

6. Bradshaw AP, Hanson JR, Hitchcock PB. $4 \alpha$ Hydroxydihydroilludin M. A new sesquiterpenoid metabolite of Clitocybe illudens. Phytochemistry 21: 942-943 (1982)

7. Matsushige K, Basnet P, Kadota S, Namba T. Potent free radical scavenging activity of dicaffeoyl quinic acid derivatives from propolis. J Trad Med 13: 217-228 (1996)

8. Re R, Pellegrini N, Proteggente A, Pannala A, Yang M, Rice Evans C. Antioxidant activity applying an improved ABTS radical cation decolorization assay. Free Radical Biol Med 26: 1231-1237 (1999)

9. Blois MS. Antioxidant determinations by the use of a stable free radical. Nature 181: 1199-1200 (1958)

10. Singh NP. Microgels for estimation of DNA strand breaks, DNA protein crosslinks and apoptosis. Mutat Res 455: 111-127 (2000)

11. Rajagopalan R, Ranjan SK, Nair CK. Effect of vinblastine sulfate on gamma-radiation-induced DNA single-strand breaks in murine tissues. Mutat Res 536: 15-25 (2003) 